\title{
Understanding Cardiopulmonary Resuscitation Determines the Readiness of Doing Basic Life Support
}

\author{
'Ulaa Haniifah' ${ }^{1} \mathbb{D}$, April Poerwanto ${ }^{2} \mathbb{D}$, Agus Sobagjo ${ }^{3}$, Maftuchah Rochmanti ${ }^{4}$
}

\begin{abstract}
${ }^{1}$ Faculty of Medicine, Universitas Airlangga, Surabaya, Indonesia.
${ }^{2}$ Department of Aneshtesiology and Reanimation, Faculty of Medicine, Universitas Airlangga/Dr. Soetomo General Hospital, Surabaya, Indonesia.

${ }^{3}$ Department of Cardiology and Vascular Medicine, Universitas Airlangga/Dr. Soetomo General Hospital, Surabaya, Indonesia. ${ }^{4}$ Department of Anatomy, Histology, and Pharmacology, Universitas Airlangga/Dr. Soetomo General Hospital, Surabaya, Indonesia.
\end{abstract}

\section{A B S T R A C T}

Introduction: Cardiopulmonary Resuscitation (CPR) is an emergency lifesaving procedure performed when the heart stops beating. Basic Life Support (BLS) is the initial action to save life-saving conditions. BLS is one of the most important components in CPR. BLS greatly determines the fate of the next life-threatening victim. This study aimed to know the relationship of understanding CPR to readiness to do BLS for students of Faculty of Medicine, Universitas Airlangga, Surabaya.

Methods: This was non-experimental study using the design of analytic and descriptive statistics. The sample of this study was the students of Faculty of Medicine, class of 2015, Universitas Airlangga, Surabaya and was taken by probability sampling method with a simple random sampling technique. Data retrieval was performed by giving a questionnaire to 100 respondents. This study was conducted in February 2019. The results of this study were then analyzed by SPSS using the Spearman test.

Results: The results of this study showed that the most level of understanding CPR was in the good category with 56 people $(56 \%)$, while the readiness to do BLS was mostly in the moderate category with 55 people (55\%). Based on the results of statistical tests using the Spearman test, there was a relationship between the level of understanding CPR and the readiness to do BLS for students of Faculty of Medicine, Universitas Airlangga, Surabaya.

Conclusion: There was relationship between the level of understanding CPR and the readiness to do BLS for students of Faculty Medicine, Universitas Airlangga, Surabaya.

\footnotetext{
*Correspondence: april.basoek@gmail.com

JUXTA: Jurnal IImiah Mahasiswa Kedokteran Universitas Airlangga p-ISSN: 1907-3623; e-ISSN: 2684-9453

DOI: 10.20473/juxta.V13I12022.13-17

Open access under Creative Commons Attribution-ShareAlike 4.0 International License (CC-BY-SA)
}

\section{ARTICLEINFO}

\section{Article history:}

Received 25 October 2021

Received in revised form 22

December 2021

Accepted 24 December 2021

Available online 5 January 2022

\section{Keywords:}

Basic life support,

Cardiopulmonary resuscitation,

Human \& health,

Readiness,

Understanding. 


\section{Introduction}

Cardiopulmonary Resuscitation (CPR) is an emergency technique for saving people who experience cardiac arrest. The CPR component consists of Basic Life Support (BLS), Advance Life Support (ALS), and Post Cardiac Arrest Care. ${ }^{1}$ BLS is part of CPR. BLS means basic actions to rescue people who are having sudden cardiac arrest. Components of BLS consist of freeing the airway (airway), providing breathing assistance (breathing), and doing a heart massage (circulation). Life-threatening emergency conditions can occur anytime, anywhere, and about anyone. Therefore, it is expected that all people who are near the victims to be able to do BLS for the initial step of saving lives. BLS is the initial action that determines the life of the next victim. ${ }^{2}$ BLS is considered a fundamental skill for health workers to save lives and improve the quality of public health. ${ }^{3}$ BLS skills are very important because it gives people basic techniques regarding how to rescue victims from various accidents or daily accidents which are often found. ${ }^{4}$ Therefore, every health worker, especially medical students, must understand and be ready to do BLS both in the hospital and out of the hospital. ${ }^{5}$ One of the most important things in CPR is BLS. This knowledge about CPR underlies the demand that all prospective medical staff or students of Faculty of Medicine, Universitas Airlangga Surabaya, understand and be able to perform BLS as an initial rescue action. Previously, the students of Faculty of Medicine, Universitas Airlangga, Surabaya had been provided with material and practice on BLS during the third semester in GELS (General Emergency Life Support) subjects. Therefore, after receiving these materials, students could understand and be able to apply them in their daily life.

Cardiac arrest is a sudden loss of function of the heart, both in people who have been diagnosed with heart disease or not. ${ }^{1,6}$ According to World Health Organization (WHO), heart attacks are still the first killer in developed and developing countries by contributing $60 \%$ of all deaths. According to the 2015 American Heart Association guidelines, the signs of cardiac arrest are unconsciousness, no reaction from the patient accompanied by no breathing or shortness of breath, and no pulses are felt within 5 seconds. If the three signs are found, immediately do a heart massage/CPR 30 times and 2 times artificial breathing. This action can save the brain as one of the vital organs which is the most susceptible to lack of oxygen. The brain can only survive if there is intake of glucose or oxygen that enters, thus the brain is classified as an organ that is vulnerable to damage. If within 5 minutes there is no circulation in the brain, the brain will die permanently. Therefore, anyone who is near the patient is expected to be able to do a heart massage after getting signs of cardiac arrest and the patient stops breathing. The main purpose of BLS is to create a blood flow which carries oxygen to vital organs such as brain and heart through circulation and artificial ventilation to make vital organs return to normal and can provide oxygen for the whole body. ${ }^{6}$
The survival of the patient will be determined through the quality of CPR. The good quality of CPR can provide the best perfusion, therefore chest compression must be deep enough, done properly, and with complete release between compression and minimal pauses in compression. ${ }^{7}$ Health workers are expected to be able to do CPR for improving health status of patients. They should increase knowledge to get good readiness in realizing health services.

This was a correlational study aimed to find the relationship between understanding $\mathrm{CPR}$ and readiness in conducting BLS for students of Faculty of Medicine, class of 2015, Universitas Airlangga, Surabaya, to emergency patients who experience cardiac arrest both in the hospital and out of the hospital.

\section{Methods}

This was an observational analytic study using a crosssectional study design. In cross-sectional studies, results and exposures in study participants are measured at the same time or at one time. Participants in the cross-sectional study are only selected based on the inclusion and exclusion criteria set for the study. ${ }^{8}$ The population taken were students of Faculty of Medicine, class of 2015 , Universitas Airlangga, Surabaya with an average age of 21 years old.

This was conducted in February 2019 in Widokausada Workshop Room Dr. Soetomo General Hospital, Surabaya. Subjects were taken randomly from the students of Faculty of Medicine, class of 2015, Universitas Airlangga, Surabaya. Each subject was given informed consent before data collection were given souvenirs. The sample was determined through the sample size formula for correlation, therefore a sample of 100 people was obtained. This study had met the ethical eligibility test by Medical Research Ethics Committee of Faculty of Medicine, Universitas Airlangga with number No. 230 / EC / KEPK / FKUA / 2018. The data were analyzed using SPSS 23.0 with the Spearman method to determine the strength of the relationship from this study.

The instrument used in this study was a questionnaire. The questionnaire given to the subject was divided into two, one of which was a questionnaire containing 10 questions to find the level of understanding of the subject of CPR theory and the second questionnaire contained 10 questions to determine the level of subject readiness in conducting BLS components, namely Airway, Breathing, Circulation. For the understanding questionnaire, subjects were asked to recall the material that was previously obtained during the GELS course. The results obtained were in the form of correct or false answers with a minimum value of 5 and a maximum value of 10 which were converted as percentages. The readiness questionnaire contained a case study of the readiness to conduct BLS. The results obtained were in the form of an ordinal scale of $1-5$, starting from 1 which was very unprepared, 2 which was not ready, 3 which was quite ready, 4 which was ready, and 5 which 
was very ready, with a minimum value of 5 and maximum value of 50 . Previously the questionnaire had been tested for validity and reliability and good results were obtained. Understanding questionnaire had $r$ value between 0.428 0.601 and crossbach - alpha value of 0.612 , and readiness questionnaire had $r$ value between 0.568 - 0.761 and crossbach - alpha value of 0.883 .

Each of the questionnaires was processed and categorized into three scales according to Ari Kunto's theory of Good, Enough, and Less. For understanding questionnaire, the subject is said to have a "Good" understanding if the correct answer is $>75 \%$, "Enough" understanding if the correct answer is $56-75 \%$, and "Less" understanding if the correct answer is $<55 \%$. For readiness questionnaire, the subject is said to have a "Good" readiness with a value of $>40$, "Enough" readiness with a value of $31-40$, and a "Less" readiness with a value of $<30$. The Spearman correlation test was conducted on the SPSS to determine the relationship between CPR understanding and readiness in conducting BLS for students of Faculty of Medicine, class of 2015, Universitas Airlangga, Surabaya. The results were obtained with a correlation coefficient of 0.197 with a $p$ value of $0.049(p>0.05)$.

\section{Results}

This study obtained 100 subjects, namely students of Faculty of Medicine, class of 2015, Universitas Airlangga, Surabaya Medical Study Program class of 2015, with an average age of 21 years old with a standard deviation of 1.109144725. From 100 students who participated as subjects, most respondents were female. The subjects consist of 40 male students and 60 female students.

\section{The Understanding of Cardiopulmonary Resuscitation}

The results of the study showed that the highest level of understanding of the subject of CPR was in the good category of 56 people (56\%), while the subjects in enough and less category were the same which equal to 22 people (22\%) (Table 1).

Table 1. Distribution of respondent frequency to understanding

\begin{tabular}{l|l|l}
\hline Understanding & Frequency & Percentage (\%) \\
& & \\
\hline Less & 22 & 22 \\
Enough & 22 & 22 \\
Good & 56 & 56 \\
\hline Total & 100 & 100 \\
\hline
\end{tabular}

The Readiness to Do Basic Life Support

Whereas for readiness in conducting BLS, 55 people $(55 \%)$ were in enough category, 41 people $(41 \%)$ were in good category, and 4 people (4\%) were in less category (Table 2).

Table 2. Distribution of respondent frequency to readiness

\begin{tabular}{l|l|l}
\hline Readiness & Frequency & Percentage (\%) \\
\hline Less & 4 & 4 \\
Enough & 55 & 55 \\
Good & 41 & 41 \\
\hline Total & 100 & 100 \\
\hline
\end{tabular}

The Relationship of Understanding Cardiopulmonary Resuscitation to Readiness of Doing Basic Life Support

Based on the results of statistical tests using the Spearman correlation test, the results obtained a correlation coefficient of 0.197 , with $p$ value of 0.049 ( $p<0.05)$. This shows that there was a relationship between the level of understanding CPR and the readiness to conduct BLS for students of Faculty of Medicine, class of 2015, Universitas Airlangga, Surabaya (Table 3). These results have a tendency if the respondent's understanding of CPR is good, their readiness to conduct BLS will also improve.

Table 3. Crosstabulation between understanding and readiness

\begin{tabular}{|c|c|c|c|c|}
\hline \multirow[t]{2}{*}{ Understanding } & \multicolumn{3}{|c|}{ Readiness } & \multirow[t]{2}{*}{ Total } \\
\hline & Less & Enough & Good & \\
\hline Less & $\begin{array}{l}1 \\
(4.5 \%)\end{array}$ & $\begin{array}{l}16 \\
(72.7 \%)\end{array}$ & $\begin{array}{l}5 \\
(22.7 \%)\end{array}$ & $\begin{array}{l}22 \\
(100 \%)\end{array}$ \\
\hline Enough & $\begin{array}{l}0 \\
(0 \%)\end{array}$ & $\begin{array}{l}14 \\
(63.6 \%)\end{array}$ & $\begin{array}{l}16 \\
(36.4 \%)\end{array}$ & $\begin{array}{l}22 \\
(100 \%)\end{array}$ \\
\hline Good & $\begin{array}{l}3 \\
(5.4 \%)\end{array}$ & $\begin{array}{l}25 \\
(44.6 \%)\end{array}$ & $\begin{array}{l}28 \\
(50 \%)\end{array}$ & $\begin{array}{l}56 \\
(100 \%)\end{array}$ \\
\hline Total & $4(4 \%)$ & $\begin{array}{l}55 \\
(55 \%)\end{array}$ & $\begin{array}{l}41 \\
(41 \%)\end{array}$ & $\begin{array}{l}100 \\
(100 \%)\end{array}$ \\
\hline
\end{tabular}

Discussion

Based on the results of the study, the highest understanding results were 56 people in the good category, who answered $>75 \%$ correct answers in the questionnaire, followed by 22 people in enough category by answering 55 $75 \%$ correct answers in the questionnaire, and 22 people in less category by answering $<55 \%$ correct answer in the questionnaire. In other studies, students of Faculty of Medicine, Udayana University, Bali had the best knowledge or understanding. The students learned how to maintain human health and performed treatment if people are sick or injured, in hope that they can return in good health. ${ }^{9}$ This is also in line with a study conducted by Rachmawaty from University of Indonesia which stated that the knowledge or understanding of CPR techniques in BLS was categorized as good because it had high knowledge. It is because the students of Faculty of Medicine specifically learned in details the technique of CPR. Another study said that students majoring in health at Saudi Women's University had very little knowledge about BLS. ${ }^{10}$ This is also similar to a study conducted bt Somaraj, et al. which stated that quite a number of dentists who were doing an internship in Mangalore, India had less knowledge. ${ }^{11}$

According to Bloom, understanding is the ability of someone to understand something after getting to know it and remember. Knowledge is one of the factors that affects the understanding of several individuals. Individual 
knowledge and understanding improves when more information is obtained. ${ }^{12}$ There are mixed results regarding the understanding of CPR because there are some differences between individuals, such as psychological conditions when receiving material or psychological conditions when filling questionnaires; physiological factors that distinguish one person from another person such as intelligence, cognitive, and motivation; and external factors, namely the environment that plays a role in supporting the successful process of absorbing knowledge and managing it into understanding. The respondents of this study were students of Faculty of Medicine, class of 2015, Universitas Airlangga, Surabaya who received CPR knowledge and managed it into a different understanding for each person because of the many factors previously mentioned, affecting the respondent when receiving material or recalling the material that was given and filling out questionnaire regarding CPR.

As for the results of readiness, the most respondents as many as 55 people were in enough category with a value of $30-40$, followed by 41 people in good category with a value $>40$, and 4 people in less category with a value $<30$. Another study conducted at Aisyiyah University Yogyakarta stated that students who had been given knowledge and training on BLS already had the desire and readiness in conducting CPR. ${ }^{13}$ Another study involving students, doctors, and nurses at colleges of medicine, dentistry, homeopathy, and nursing in India had a very poor awareness and readiness for BLS. ${ }^{14}$ According to Mangkuprawira, training is a process of teaching certain knowledge, expertise, and attitude to make someone more skilled and able to perform responsibilities better in accordance with the standards. ${ }^{15}$ Thus, it can be said that good knowledge and understanding of CPR and training will create readiness in conducting BLS.

The results of this study indicated that there was a relationship between the level of understanding CPR and the readiness to conduct BLS for students of Faculty of Medicine, class of 2015, Universitas Airlangga, Surabaya. Based on the results, this study also found a tendency if the respondent's understanding improves, the respondent's readiness can improve as well. According to Notoadmodjo, knowledge is very closely related to readiness. For example, if a health worker finds a patient in cardiac arrest, in making a decision on what they should do, the health worker must have good knowledge about cardiac arrest at evaluation level to prevent mistreatment. Evaluation is the highest level of knowledge because it involves the ability to make an assessment of a material or object. This is not in line with a study conducted by Aminuddin which stated that there are many nurses or health workers who have good knowledge but are not ready to handle cardiac arrest patients and perform CPR. This is due to other factors that affect the experience or length of work and available facilities. Based on the length of work, the longer the nurse works, the more experience they have in their life to deal with cardiac arrest patients. Based on facilities, incomplete facilities can reduce the level of readiness of nurses or health workers in conducting BLS. According to Wollf, experience and training also affect the readiness of health workers or nurses. Based on the previous statement, it can be concluded that the readiness of BLS is not only limited to a good understanding but also influenced by experience, training, and readiness of good support tools.

As commonly found in a study, there are advantages and disadvantages. The advantage of this study is that this kind of study had never been done before in Faculty of Medicine, Universitas Airlangga, while the disadvantages are the limitations of respondents who were only limited to 100 people, only conducted in one batch of students, and only used one variable which affected BLS in this study.

\section{Conclusion}

Based on the results of the study regarding the relationship between the level of understanding CPR and the readiness to conduct BLS for students of Faculty of Medicine, class of 2015, Universitas Airlangga, Surabaya, the understanding of CPR of 100 respondents was categorized as good, and the readiness in conducting BLS was categorized as well. It can be concluded that there was a relationship between the level of understanding CPR and the readiness to conduct BLS for students of Faculty of Medicine, class of 2015, Universitas Airlangga, Surabaya.

\section{CONFLICT OF INTEREST}

The author stated there is no conflict of interest in this study.

\section{REFERENCES}

1. American Heart Association. Fokus Utama Pembaruan Pedoman American Heart Association 2015 untuk CPR dan ECC. Am Hear Assoc 2015; 132: 293.

2. Fakultas Kedokteran Universitas Airlangga. Pelatihan GELS (General Emergency Life Support) PPGD (Penanggulangan Penderita Gawat Darurat). Surabaya, 2012.

3. Selvaraj V, Parajulee S. Knowledge of Nurses Towards Cardio-Pulmonary Resuscitation in a Tertiary Care Teaching Hospital in Nepal. J Clin Diagnostic Res 2013; 9: 7-13.

4. Hasanah UN. Hubungan Tingkat Pengetahuan dengan Ketrampilan Perawat dalam Melakukan Tindakan Bantuan Hidup Dasar ( BHD) di RSUD Kabupaten Karanganyar. Stikes Kusuma Husada Surakarta, 2015.

5. Keenan M, Joubert G, Lamacraft G. A Survey of Nurses' Basic Life Support Knowledge and Training at a Tertiary Hospital. African J Heal Prof Educ 2009; 1 : 3-7.

6. Field JM, Hazinski MF, Sayre MR, et al. Part 1: Executive summary: 2010 American Heart Association Guidelines for Cardiopulmonary Resuscitation and Emergency Cardiovascular Care. Circulation 2010; 122: 640-656.

7. Davok D. CPR Quality and Education. The University of Eastern Finland, http://www.scielo.br/scielo.php?pid=S141440772007000300007\&script=sci_arttext (2010).

8. Setia M. Methodology Series Module 3: Cross-sectional Studies. Indian J Dermatol 2016; 61: 261-264. 
9. Suranadi I. Tingkat Pengetahuan tentang Bantuan Hidup Dasar (BHD) Mahasiswa Fakultas Kedokteran Universitas Udayana. Universitas Udayana, 2017.

10. Al-Mohaissen MA. Knowledge and Attitudes towards Basic Life Support among Health Students at a Saudi Women's University. Sultan Qaboos Univ Med J 2017; 17: e59-e65.

11. Somaraj V, Shenoy RP, Panchmal GS. Knowledge, Attitude and Anxiety Pertaining to Basic Life Support and Medical Emergencies among Dental Interns in Mangalore City, India. World J Emerg Med 2017; 8: 131.

12. Mubarak W. Promosi Kesehatan: Sebuah Pengantar Proses Belajar Mengajar dalam Pendidikan. Yogyakarta: Graha IImu, 2007.

13. Hernando G. Pengaruh Pelatihan Basic Life Support terhadap Tingkat Kesiapan Melakukan Cardiopulmonary Resuscitation pada Mahasiswa Keperawatan Universitas Aisyiyah Yogyakarta. Universitas 'Aisyiyah, 2016.

14. Chandrasekaran S, Kumar S, Bhat SA, Shabbir PM, Chandrasekaran VP. Awareness of Basic Life Support among Medical, Dental, Nursing Students and Doctors. Indian J Anaesth 2010; 54: 121-126.

15. Riyani A. Pengaruh Pelatihan Basic Life Support terhadap Pengetahuan dan Ketrampilan Mahasiswa Keperawatan tentang Kegawatdaruratan di Fakultas IImu Kesehatan Universitas Muhammadiyah Purwokerto. Universitas Muhammadiyah Purwokerto, http://repository.ump.ac.id/681/ (2016). 